\title{
Small spatial scale population genetic structure in two limpet species endemic to the Kermadec Islands, New Zealand
}

\author{
Ann R. Wood*', Jonathan P. A. Gardner \\ Centre for Marine Environmental and Economic Research, School of Biological Sciences, Victoria University of Wellington, \\ PO Box 600, Wellington, New Zealand
}

\begin{abstract}
Persistence of marine species in isolated habitats requires either continuing recruitment from distant sources or self-recruitment from the local population. Species endemic to small isolated oceanic islands such as the SW Pacific Kermadec Islands (New Zealand) are reliant on self-recruitment for continued existence. Population genetic studies in such isolated habitats can provide data on the extent to which dispersal limits the occurrence of organisms and determines their genetic structure. We used randomly amplified polymorphic DNA markers (RAPDs) to examine genetic structuring and connectivity among populations of 2 intertidal limpets endemic to the Kermadec Islands. Significant genetic differentiation and limited connectivity were observed among populations of these limpets separated by less than $1 \mathrm{~km}$, suggesting that a large proportion of successfully recruiting larvae do not disperse far from their population of origin. Patterns of connectivity may be explained partly by the geographic distance among populations, but the data suggest that other barriers to gene flow, most likely associated with local hydrographic features, contribute to the observed patterns of small-scale population genetic structuring.
\end{abstract}

KEY WORDS: Population genetic variation · Gene flow · Self-recruitment • Scutellastra kermadecensis $\cdot$ Siphonaria raoulensis $\cdot$ RAPDs $\cdot$ Kermadec Islands Marine Reserve $\cdot$ SW Pacific

\section{INTRODUCTION}

Understanding patterns of genetic variation and population structure within species can provide important insight into the ability of populations and species to evolve to cope with environmental change, and hence, their chances of long-term survival. Several studies have suggested that reproductive performance and evolutionary adaptive potential are improved when genetic variation is spatially structured (e.g. Frankham et al. 2002). However, where gene flow is restricted, population fragmentation tends to lead to inbreeding and loss of genetic diversity within fragments. Inbreeding reduces fecundity and survival and so directly increases extinction risk of local populations. Reduced genetic diversity compromises evolutionary potential and decreases the chance of long-term persistence; therefore, the maintenance of genetic diversity is a major focus in conservation biology (Frankham et al. 2002).

Gene flow over great distances is thought to occur in many marine organisms via the dispersal of a planktonic larval stage. Indeed, homogeneity of allele frequencies over thousands of kilometres detected in several marine organisms lends support to this idea (e.g. sea urchins, Lessios et al. 1998). However, a growing body of recent evidence suggests that in many cases, planktonic larvae are retained close to where they were produced, and therefore, that actual levels of gene flow among populations may be much lower than the potential values estimated from larval lifespan and oceanographic data (e.g. Swearer et al. 1999). Island archipelagos may promote such local retention of larvae by disrupting the flow of currents (Scheltema 
1986), and several studies have found increased genetic subdivision within island groups compared to relative genetic homogeneity across wider oceanic or coastal distances (e.g. intertidal snails, Johnson \& Black 2006).

The Kermadec Islands are an isolated chain of active volcanoes rising over $1 \mathrm{~km}$ above the Kermadec Ridge, approximately midway between mainland New Zealand and Tonga. The 11 Kermadec islands are approximately 0.6 to $1.4 \mathrm{M}$ yr old (Gabites Appendix 2 in Lloyd \& Nathan 1981), and form 3 discrete groups: the northern $\left(29^{\circ} 15^{\prime} \mathrm{S}, 177^{\circ} 55^{\prime} \mathrm{W}\right)$, the middle $\left(30^{\circ} 14^{\prime} \mathrm{S}\right.$, $\left.178^{\circ} 25^{\prime} \mathrm{W}\right)$, and the southern group $\left(31^{\circ} 21^{\prime} \mathrm{S}, 178^{\circ}\right.$ $48^{\prime} \mathrm{W}$; Fig. 1). As 1 of the few subtropical island groups of the SW Pacific Ocean, located a minimum of $750 \mathrm{~km}$ distant from other landmasses in all directions, the Kermadec Islands are of considerable biogeographic interest and have been protected by the New Zealand Department of Conservation as a no-take marine reserve since 1990. A large proportion of the marine fauna is endemic, and although the currents in this area are not well described, it is likely that dispersal of shallow-water marine organisms to the Kermadecs from other locations is rare. Because of the large number of endemic species and the young age and isolation of the islands, the genetic structure of and connectivity among populations of endemic Kermadec species are of significant evolutionary and conservation interest.

To better understand population genetic structuring and levels of connectivity among sites in the Kermadec Islands, we used randomly amplified polymorphic DNA markers (RAPDs; Welsh \& McClelland 1990) to study 2 relatively abundant gastropod molluscs: the giant Kermadec limpet Scutellastra kermadecensis Pilsbry, 1894 (Prosobranchia: Patellidae) and the pulmonate limpet Siphonaria raoulensis Oliver, 1915 (Pulmonata: Siphonariidae), which are endemic to the Kermadec Islands (Oliver 1915, Brook 1998a). Both species have sedentary adult stages that occupy obvious home scars on rocky shores. S. kermadecensis is the dominant grazing invertebrate in the low intertidal

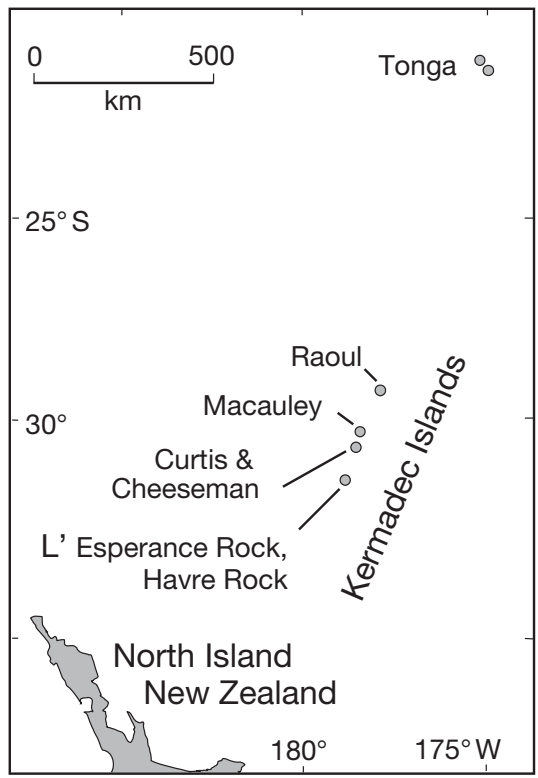

Fig. 1. Geographic location of the Kermadec Islands, showing northern (Raoul \& nearby islets), middle (Macauley, Curtis, Cheeseman) and southern (L'Esperance, Havre) groups. Arrows indicate sampling sites: DAY, Dayrell Island; $\mathrm{WCH}_{\text {, }}$ West Chanter Island; NAP, Napier Island; NUG, Nugent Island; MEY, Meyer Island; EGE, Egeria Rock; BOA, Boat Landing; MIL, Milne Islets; DEN, Denham Bay; MAC, Macauley Island; CUR, Curtis Island
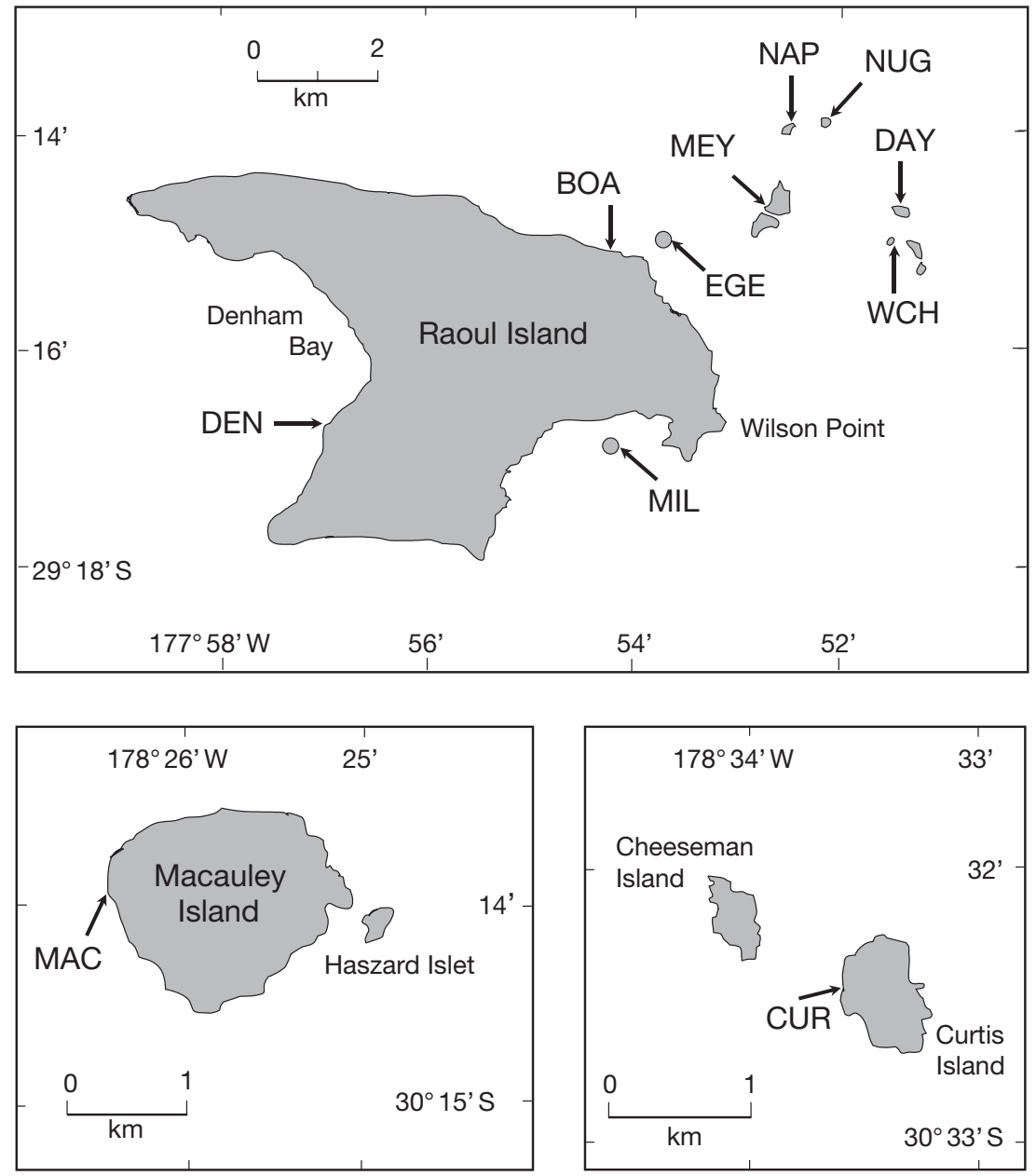
and shallow subtidal zones, commonly reaching a shell length $>130 \mathrm{~mm}$ and densities of up to $40 \mathrm{~m}^{-2}$ (Cole et al. 1992, pers. obs.). The Patellidae are broadcast spawners with pelagic larvae (Lindberg 1988), and like several other patellid limpets, S. kermadecensis is a protandrous sequential hermaphrodite (Creese et al. 1990). Nothing is known about its larval stage, although estimates of the pelagic larval lifespan of European Patella species range from 4 to $10 \mathrm{~d}$ (Dodd 1957). Fossil $S$. kermadecensis have been recorded from the early Pleistocene in the northern Kermadec Islands (Brook 1998b), and it is thought that the present-day species may be a relict of a species that occurred around mainland New Zealand during the Oligocene (Fleming 1973). Oliver (1915) recorded several intertidal Siphonaria species at Raoul (S. raoulensis, S. cheesemani, S. macauleyensis and S. amphibia), but in a more recent review of coastal molluscs, Brook (1998a) suggested that there is only 1 morphologically variable Siphonaria species, S. raoulensis, in the northern Kermadec Islands. The reproductive biology of $S$. raoulensis is unknown, but inferences about its likely reproductive strategy can be made from studies of congeners. The Siphonariidae are hermaphrodites with internal fertilisation, laying their eggs in ribbons that are usually cemented to intertidal rocks, with the exception of 2 species that release pelagic egg masses (Hodgson 1999). Most Siphonaria species produce numerous small eggs that hatch into planktotrophic larvae, and estimates of planktonic lifespan range from $9 \mathrm{~d}$ to $10 \mathrm{wk}$. Other Siphonaria species deposit fewer larger eggs that undergo direct development into crawling juveniles, and 2 species produce pediveliger larvae (Hodgson 1999).

Study of the population genetic variation of these 2 endemic limpets provides a rare opportunity to test hypotheses about the extent of gene flow across the entire known range of 1 or more taxa. Because these limpets are endemic to the Kermadec Islands, they must, by definition, rely on self-recruitment for persistence. However, the level of connectivity among islands, and hence the spatial scale at which selfrecruitment predominates, is unknown. Given that the Kermadec Island group is small and geologically young, our null hypothesis predicts that there is no detectable population genetic structuring for these 2 species, either within island groups or between them.

\section{MATERIALS AND METHODS}

Sample collection. Scutellastra kermadecensis and Siphonaria raoulensis were collected from 6 intertidal sites on islands and islets close to Raoul Island (northern Kermadec Islands) in July 2002. S. kermadecensis were also collected from a seventh site in the same region in July 2002 and from 4 further sites, including Macauley and Curtis Islands (middle group of the Kermadec Islands), in November 2004 (Fig. 1). Samples were preserved in $95 \%$ ethanol prior to DNA extraction. Because of rough weather, we were unable to collect samples from the southern group (L'Esperance Rock and Havre Rock) on either cruise. In the following text we refer to the northern and middle (as opposed to northern and southern) groups of islands for geographic accuracy and in case it is possible to obtain samples from the southern island group at a later date to enhance the analyses presented here.

DNA extraction and PCR amplification. Total DNA was extracted from approximately $20 \mathrm{mg}$ of foot tissue from each limpet using the DNeasy tissue kit (Qiagen), following the manufacturer's instructions. DNA was eluted in sterile $10 \mathrm{mM}$ Tris- $\mathrm{HCl}(\mathrm{pH} 8)$ and stored at $4^{\circ} \mathrm{C}$. DNA concentration was estimated by comparison to a High DNA Mass ladder (Invitrogen) on an ethidium bromide-stained $0.8 \%$ agarose gel. Only those samples that showed good quality high molecular weight DNA were used for RAPD analysis.

Forty decamer oligonucleotide primers (OPC-01 to OPC-20 and OPE-01 to OPE-20, Operon Technologies) were tested on 2 individuals from a single site (DAY; see Fig. 1 for sampling site abbreviations) for each species. Primers that produced clear, easily scorable bands (9 primers for Scutellastra kermadecensis, 8 for Siphonaria raoulensis) were used to screen 5 individuals from each of 2 sites (DAY and MEY). For each species, 3 primers were selected for use in the main study, based on their ability to generate a large number (in relation to other primers screened) of reproducible and unambiguously scorable bands. These primers were $\left(5^{\prime}\right.$ to $\left.3^{\prime}\right)$ : OPC-06 (GAACGGACTC), OPE-05 (TCAGGGAGGT) and OPE-11 (GAGTCTCAGG) for S. kermadecensis and OPC-04 (CCGCATCTAC), OPE-06 (AAGACCCCTC) and OPE-12 (TTATCGCCCC) for $S$. raoulensis. For these primers, reproducibility was confirmed in the 5 DAY and 5 MEY individuals by consistent amplification of all strong bands in 3 separate PCRs. Some faint bands showed inconsistent amplification across PCRs; therefore, scoring was restricted to strong, reproducible bands. In addition, following population screening, reproducibility of banding profiles was confirmed by repeating PCRs twice for $10 \%$ of individuals ( 2 per population, total 34 ), selected to include all bands scored for each primer. A negative control, with no template DNA added, was included in each set of PCR amplifications.

For all PCR amplifications, the $25 \mu \mathrm{l}$ reaction mixture contained $20 \mathrm{mM}$ Tris- $\mathrm{HCl}, 50 \mathrm{mM} \mathrm{KCl}, 2 \mathrm{mM} \mathrm{MgCl}_{2}$, $0.2 \mathrm{mM}$ of each dNTP, $0.2 \mu \mathrm{M}$ of a single decamer primer, 1 unit Taq DNA polymerase (Invitrogen) and 
10 ng template DNA. All amplifications were performed in an Applied Biosystems GeneAmp 2700 thermocycler, preheated to $94^{\circ} \mathrm{C}$ and programmed for 40 cycles: 4 initial cycles of $3 \mathrm{~min}$ at $94^{\circ} \mathrm{C}, 3 \mathrm{~min}$ at $36^{\circ} \mathrm{C}$ and $3 \mathrm{~min}$ at $72^{\circ} \mathrm{C}_{i}$ followed by 36 cycles of $30 \mathrm{~s}$ at $94^{\circ} \mathrm{C}, 1 \mathrm{~min}$ at $36^{\circ} \mathrm{C}, 2 \mathrm{~min}$ at $72^{\circ} \mathrm{C}$; and a final extension period of $8 \mathrm{~min}$ at $72^{\circ} \mathrm{C}$. PCR products were electrophoresed on $1.4 \%$ agarose gels, stained with ethidium bromide and visualised using UV illumination. Gels were photographed using a Kodak DC 4800 digital camera with an orange filter.

Data analysis. The digital gel images were inverted and the contrast was increased using Microsoft Photo Editor. The gel images were then laser printed, and bands in the size range 350 to $2750 \mathrm{bp}$ were scored for presence or absence in each individual. Only bands that were reproducible and could be scored unambiguously across all individuals were included in the analysis. To estimate band scoring error, all gels were scored a second time (at least $2 \mathrm{wk}$ after the first scoring) by the same person (A. R. Wood), without reference to the results of the first scoring. The number of bands scored differently was 3 (out of 7626) for Scutellastra kermadecensis and 8 (out of 11837) for Siphonaria raoulensis, giving an insignificant error rate $(<0.001)$ for each species. Each band was treated as a putative locus with 2 alleles (band presence or absence), and the binary data from each primer were combined to construct a multilocus RAPD phenotype for each individual.

With the assumption that each RAPD locus was in Hardy-Weinberg equilibrium, allele frequencies were estimated using the Bayesian method of Zhivotovsky (1999) with a non-uniform prior distribution, implemented in AFLP-SURV v1.0 (Vekemans 2002). This method gives unbiased estimates of gene diversity and population genetic structure from dominant markers (Zhivotovsky 1999, Krauss 2000). The number of polymorphic loci at the $5 \%$ level, i.e. with allele frequencies within the range 0.05 to 0.95 , and Nei's gene diversity $(H)$ were also computed in AFLP-SURV, for each species at each site.

Estimates of population genetic structure were obtained for each species and also, for comparative purposes, for a 6-population subset of the Scutellastra kermadecensis dataset including only the populations also available for Siphonaria raoulensis (i.e. only DAY, WCH, NAP, MEY, EGE and MIL). Wright's fixation index, $F_{\mathrm{ST}}$, was computed in AFLP-SURV, and genetic differentiation among populations was tested using a permutation test with 5000 pseudoreplicates. For comparison, and because of its facility to estimate hierarchical structure, analysis of molecular variance (AMOVA) was carried out using GenAlEx v6 (Peakall \& Smouse 2006). Using a matrix of squared Euclidean distances (the Binary option in GenAlEx) computed from individual multilocus phenotypes, AMOVA calculates an $F_{\mathrm{ST}}$ analogue $\left(P H I_{\mathrm{PT}}\right)$, which estimates variation among regions, among populations within regions, and among individuals within populations. AMOVA gives estimates of population genetic structure from dominant markers concordant with those estimated from co-dominant markers (Isabel et al. 1999). Pairwise population $P H I_{\mathrm{PT}}$ values and estimates of gene flow $(\mathrm{Nm}$, number of migrants per generation $\left.=0.25\left[\left(1 / P H I_{\mathrm{PT}}\right)-1\right]\right)$ were also calculated in GenAlEx. Indirect estimation of $\mathrm{Nm}$ from $\mathrm{PHI}_{\mathrm{PT}}$ involves numerous assumptions such as constant population size, random migration, and no selection, mutation or spatial structure, that are often violated in natural populations (Whitlock \& McCauley 1999). Although these indirect estimates of $\mathrm{Nm}$ must be interpreted with caution, they can still provide useful information about the approximate magnitude of gene flow (Neigel 2002). To complement the $\mathrm{Nm}$ values, which estimate average gene flow over many generations, we used assignment tests to provide direct estimates of contemporary dispersal. Assignment tests make few assumptions (Hardy-Weinberg equilibrium, no linkage disequilibrium) and give dispersal estimates comparable to those from mark-and-recapture data (Berry et al. 2004). Assignment tests were performed using the method of Paetkau et al. (1995) with the Doh assignment test calculator for dominant marker data (available at: http://www2.biology.ualberta.ca/jbrzusto/ Doh.php) to determine the accuracy with which individuals could be assigned to their population or group (i.e. northern vs. middle) of collection.

To investigate relationships among populations, UPGMA cluster analysis was carried out using PAUP v4.0b10 (Swofford 2002), from a matrix of Nei's genetic distances between populations. Confidence estimates for nodes were generated by analysing 1000 bootstrap replicates of the distance matrix generated in AFLPSURV. Principal coordinates analysis ( $\mathrm{PCoA})$ of the individual by individual binary genetic distance matrix used for AMOVA was carried out using the standardised distance matrix method in GenAlEx.

Minimum marine distances $(\mathrm{km})$ between sampling sites were measured from Land Information New Zealand chart NZ2225. A Mantel test was carried out using GenAlEx, with the null hypothesis that genetic distance (represented by a linear version of the binary distance matrix described above) between populations was not correlated to geographical distance (minimum marine distance, in $\mathrm{km}$ ). Spatial genetic structure was further investigated using Spatial Autocorrelation analysis in GenAlEx. This procedure tests for the presence of individual spatial genetic structure 
in a multilocus dataset using the method of Smouse \& Peakall (1999). A correlation coefficent, r, between linear genetic and geographic distances was calculated for all pairs of individuals within specified geographic distance classes. To maximise resolution, we selected the smallest possible distance classes, with the constraint of a minimum sample size of 500 pairwise comparisons per class. For each distance class, $\mathrm{r}$ was considered statistically significant if it exceeded the $95 \%$ confidence interval around the null hypothesis of no spatial structure, i.e. $r=0$ (calculated from 9999 permutations of the data) and if the $95 \%$ confidence interval around $\mathrm{r}$ (determined from 1000 bootstrap replicates) did not contain 0 . To estimate the extent of spatial genetic structure, we calculated $r$ for increasing distance class sizes from the minimum to the maximum distance between samples (in this case 0.5 to $150 \mathrm{~km}$ for Scutellastra kermadecensis and 1 to $7 \mathrm{~km}$ for Siphonaria raoulensis). When significant spatial genetic structure is present, the value of $r$ for the shortest distance class will decrease with increasing distance class size. The distance class size at which the value of $r$ becomes non-significant indicates the extent of positive spatial genetic structure (Peakall et al. 2003).

\section{RESULTS}

The number of bands scored for each primer ranged from 16 to 30, and the total number of loci scored was 54 for Scutellastra kermadecensis and 89 for Siphonaria raoulensis. The average number of bands scored per individual was $19.6 \pm 2.2$ (mean $\pm \mathrm{SD}$ ) for $S$. kermadecensis and $21.7 \pm 4.8$ for $S$. raoulensis (Table 1 ). The percentage of polymorphic loci at the $5 \%$ level was considerably lower for S. kermadecensis (mean 54.5\%) than for $S$. raoulensis (mean $87.1 \%$ ). We detected 1, 1 and 2 private bands in the $S$. kermadecensis samples from WCH, DEN and CUR, respectively, but no private bands were detected in any of the $S$. raoulensis populations. The number of unique multilocus genotypes observed was 189 in the 192 S. kermadecensis individuals analysed, with 3 genotypes shared by 2 individuals each. One of these shared genotypes occurred in 2 individuals from NAP, the second in individuals from $\mathrm{BOA}$ and $\mathrm{WCH}$, and the third in individuals from BOA and NAP. Each of the 133 S. raoulensis individuals analysed had a different multilocus genotype. Nei's gene diversity within populations $(H)$ was lower in $S$. kermadecensis (mean \pm SE: $0.165 \pm 0.005)$ than in $S$. raoulensis $(0.224 \pm 0.005$; Table 1$)$.

Table 1. Scutellastra kermadecensis and Siphonaria raoulensis. Summary of randomly amplified polymorphic DNA marker (RAPD) loci and Nei's gene diversity for each sampling site. See Fig. 1 for sampling site abbreviations

\begin{tabular}{|c|c|c|c|c|c|}
\hline $\begin{array}{l}\text { Species and } \\
\text { sampling site }\end{array}$ & $\begin{array}{l}\text { Sample } \\
\text { size }\end{array}$ & $\begin{array}{l}\text { No. of polymorphic } \\
\text { loci }^{\text {a }}\end{array}$ & $\begin{array}{l}\text { No. of private } \\
\text { bands }\end{array}$ & $\begin{array}{c}\text { No. of bands scored } \\
\text { per individual (mean } \pm \text { SD) }\end{array}$ & $\begin{array}{l}H(\text { Nei's gene } \\
\text { diversity } \pm \mathrm{SE})^{\mathrm{b}}\end{array}$ \\
\hline \multicolumn{6}{|c|}{ Scutellastra kermadecensis } \\
\hline \multicolumn{6}{|l|}{ Northern group } \\
\hline DAY & 21 & 26 & 0 & $18.19 \pm 1.40$ & $0.144 \pm 0.023$ \\
\hline $\mathrm{WCH}$ & 19 & 27 & 1 & $19.89 \pm 2.73$ & $0.154 \pm 0.023$ \\
\hline NAP & 20 & 26 & 0 & $20.25 \pm 2.17$ & $0.153 \pm 0.025$ \\
\hline NUG & 20 & 29 & 0 & $21.05 \pm 1.50$ & $0.154 \pm 0.023$ \\
\hline MEY & 11 & 34 & 0 & $18.27 \pm 2.05$ & $0.186 \pm 0.025$ \\
\hline EGE & 20 & 33 & 0 & $19.60 \pm 1.57$ & $0.162 \pm 0.021$ \\
\hline BOA & 18 & 30 & 0 & $19.50 \pm 1.54$ & $0.168 \pm 0.023$ \\
\hline MIL & 19 & 31 & 0 & $17.53 \pm 2.57$ & $0.173 \pm 0.023$ \\
\hline $\mathrm{DEN}$ & 18 & 33 & 1 & $20.56 \pm 2.09$ & $0.177 \pm 0.022$ \\
\hline \multicolumn{6}{|l|}{ Middle group } \\
\hline MAC & 4 & 30 & 0 & $22.25 \pm 1.50$ & $0.201 \pm 0.024$ \\
\hline CUR & 22 & 25 & 2 & $20.27 \pm 1.98$ & $0.143 \pm 0.024$ \\
\hline \multicolumn{6}{|c|}{ Siphonaria raoulensis } \\
\hline DAY & 22 & 83 & 0 & $23.00 \pm 6.06$ & $0.236 \pm 0.012$ \\
\hline $\mathrm{WCH}$ & 22 & 80 & 0 & $23.45 \pm 4.46$ & $0.238 \pm 0.013$ \\
\hline NAP & 20 & 75 & 0 & $22.15 \pm 3.50$ & $0.230 \pm 0.011$ \\
\hline MEY & 20 & 69 & 0 & $21.15 \pm 5.90$ & $0.219 \pm 0.012$ \\
\hline EGE & 24 & 77 & 0 & $20.79 \pm 3.36$ & $0.210 \pm 0.012$ \\
\hline MIL & 25 & 81 & 0 & $20.08 \pm 4.71$ & $0.209 \pm 0.011$ \\
\hline
\end{tabular}


The UPGMA cluster analyses based on Nei's genetic distance among populations revealed different patterns of clustering in the 2 species (Fig. 2). For Scutellastra kermadecensis, populations were divided with moderate bootstrap support $(73 \%)$ into 1 clade containing both middle (MAC, CUR) and northern (DEN, MIL) populations, and a second clade containing the remaining 7 northern populations. For Siphonaria raoulensis, MEY and MIL were the most closely related populations, forming a clade with NAP and DAY, outside which lay WCH and EGE.

Estimates of $P H I_{\mathrm{PT}}$ from AMOVA were consistently higher (by a factor of 1.5 to 3 ) than $F_{\mathrm{ST}}$ estimates from AFLP-SURV (Table 2). For Siphonaria raoulensis, a small but statistically significant level of variation was detected among the 6 populations $\left(F_{\mathrm{ST}}=0.015, \mathrm{p}<\right.$ 0.0001; $P H I_{\mathrm{PT}}=0.046, \mathrm{p}<0.001$ ). Pairwise population $P H I_{\mathrm{PT}}$ values for $S$. raoulensis ranged from 0.019 to 0.081 and, after Bonferroni correction for multiple testing (Rice 1989), values for 12 of 15 comparisons were significantly greater than 0 (Table 3 ). Pairwise population estimates of gene flow $(\mathrm{Nm})$ for $S$. raoulensis ranged from 2.821 to 12.72 migrants per generation (Table 3). Moderate variation was detected among the 11 Scutellastra kermadecensis populations $\left(F_{\mathrm{ST}}=\right.$ $\left.0.111, \mathrm{p}=0.0004 ; P H I_{\mathrm{PT}}=0.177, \mathrm{p}<0.001\right)$. Pairwise population $\mathrm{PHI}_{\mathrm{PT}}$ values for $S$. kermadecensis ranged from 0.024 to 0.373 and, after Bonferroni correction for multiple testing (Rice 1989), were significantly greater than 0 in 46 out of 55 comparisons (Table 4). In case the small sample size for MAC $(n=4)$ might be causing bias, we repeated the analyses excluding the MAC population. For the remaining 10 populations, among-population variation was only slightly lower $\left(F_{\mathrm{ST}}=0.098, \mathrm{p}<0.0001 ; P H I_{\mathrm{PT}}=0.172, \mathrm{p}<0.001\right)$. When only the 6 sites sampled for both species were included in the analysis, among-population variation was considerably higher for $S$. kermadecensis than for S. raoulensis (Table 2).

Hierarchical AMOVA analysis for Scutellastra kermadecensis was used to assess the level of genetic variation between the northern and middle sampling sites by partitioning the total genetic variation into 3 components: among regions, among populations within regions, and among individuals within populations (Table 5). Dividing the populations into regions according to the groupings observed in the UPGMA dendrogram (region $1=$ MAC, CUR, DEN, MIL; region 2 = all remaining populations) resulted in greater among-region variation than when regions were defined according to an a priori grouping of middle and northern sites (region $1=\mathrm{MAC}$, CUR; region $2=$ all remaining populations). The highest pairwise population $P H I_{\mathrm{PT}}$ values observed were between MAC/CUR and the northern populations (excluding

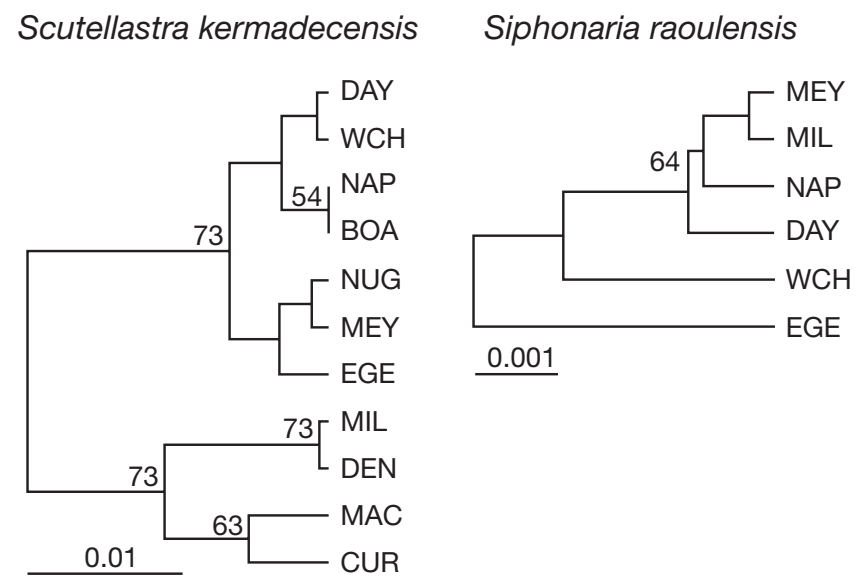

Fig. 2. Scutellastra kermadecensis and Siphonaria raoulensis. UPGMA trees based on Nei's genetic distances among populations. Bootstrap support values $(>50 \%)$ are given at nodes

Table 2. Scutellastra kermadecensis and Siphonaria raoulensis. Estimates of population genetic structure. See Fig. 1 for sampling site abbreviations

\begin{tabular}{|c|c|c|}
\hline Species (no. populations) & $F_{\mathrm{ST}}{ }^{\mathrm{a}}$ & $P H I_{\mathrm{PT}}{ }^{\mathrm{b}}$ \\
\hline \multicolumn{3}{|l|}{ Scutellastra kermadecensis } \\
\hline 11 populations & $\begin{array}{c}0.111 \\
\mathrm{p}=0.0004\end{array}$ & $\begin{aligned} & 0.177 \\
\mathrm{p} & <0.001\end{aligned}$ \\
\hline $\begin{array}{l}6 \text { populations (DAY, WCH, } \\
\text { NAP, MEY, EGE, MIL) }\end{array}$ & $\begin{array}{c}0.077 \\
\mathrm{p}<0.0001\end{array}$ & $\begin{aligned} & 0.145 \\
\mathrm{p} & <0.001\end{aligned}$ \\
\hline \multicolumn{3}{|l|}{ Siphonaria raoulensis } \\
\hline 6 populations & $\begin{array}{c}0.015 \\
\mathrm{p}<0.0001\end{array}$ & $\begin{aligned} & 0.046 \\
\mathrm{p} & <0.001\end{aligned}$ \\
\hline \multicolumn{3}{|c|}{$\begin{array}{l}{ }^{a} \text { Wright's fixation index, calculated from Bayesian esti- } \\
\text { mates of allele frequencies. Probability values based on } \\
5000 \text { permutations } \\
{ }^{\mathrm{b} C a l c u l a t e d ~ f r o m ~ a ~ m a t r i x ~ o f ~ s q u a r e d ~ E u c l i d e a n ~ d i s-~} \\
\text { tances using AMOVA. Probability values based on } 9999 \\
\text { permutations }\end{array}$} \\
\hline
\end{tabular}

Table 3. Siphonaria raoulensis. Pairwise population $P H I_{\mathrm{PT}}$ values (below diagonal) and $\mathrm{Nm}$ values based on 9999 permutations (above diagonal) from AMOVA. $P H I_{\mathrm{PT}}$ values given in bold were significantly greater than 0 at the $5 \%$ level after Bonferroni correction for multiple testing. See Fig. 1 for sampling site abbreviations

\begin{tabular}{|lcccccc|}
\hline & DAY & WCH & NAP & MEY & EGE & MIL \\
\hline DAY & - & 4.081 & 8.081 & 10.775 & 3.271 & 7.071 \\
WCH & $\mathbf{0 . 0 5 8}$ & - & 7.807 & 3.456 & 3.500 & 4.555 \\
NAP & $\mathbf{0 . 0 3 0}$ & $\mathbf{0 . 0 3 1}$ & - & 7.141 & 2.821 & 12.721 \\
MEY & 0.023 & $\mathbf{0 . 0 6 7}$ & $\mathbf{0 . 0 3 4}$ & - & 3.480 & 12.124 \\
EGE & $\mathbf{0 . 0 7 1}$ & $\mathbf{0 . 0 6 7}$ & $\mathbf{0 . 0 8 1}$ & $\mathbf{0 . 0 6 7}$ & - & 7.406 \\
MIL & $\mathbf{0 . 0 3 4}$ & $\mathbf{0 . 0 5 2}$ & 0.019 & 0.020 & $\mathbf{0 . 0 3 3}$ & - \\
\hline
\end{tabular}


Table 4. Scutellastra kermadecensis. Pairwise population $P H I_{\mathrm{PT}}$ values (below diagonal) and Nm values based on 9999 permutations (above diagonal) from AMOVA. $P H I_{\mathrm{PT}}$ values given in bold were significantly greater than 0 at the $5 \%$ level after Bonferroni correction for multiple testing. See Fig. 1 for sampling site abbreviations

\begin{tabular}{|lccccccccccc|}
\hline & DAY & WCH & NAP & NUG & MEY & EGE & BOA & MIL & DEN & MAC & CUR \\
\hline DAY & - & 10.138 & 2.529 & 2.983 & 1.813 & 1.549 & 2.589 & 0.959 & 1.129 & 0.467 & 0.532 \\
WCH & 0.024 & - & 8.003 & 2.832 & 1.748 & 2.359 & 5.254 & 0.944 & 1.624 & 0.578 & 0.571 \\
NAP & $\mathbf{0 . 0 9 0}$ & 0.030 & - & 2.684 & 1.473 & 1.891 & 8.090 & 0.727 & 1.090 & 0.420 & 0.464 \\
NUG & $\mathbf{0 . 0 7 7}$ & $\mathbf{0 . 0 8 1}$ & $\mathbf{0 . 0 8 5}$ & - & 6.311 & 3.320 & 2.438 & 0.791 & 1.142 & 0.642 & 0.614 \\
MEY & $\mathbf{0 . 1 2 1}$ & $\mathbf{0 . 1 2 5}$ & $\mathbf{0 . 1 4 5}$ & 0.038 & - & 4.660 & 1.482 & 0.888 & 1.154 & 0.822 & 0.689 \\
EGE & $\mathbf{0 . 1 3 9}$ & $\mathbf{0 . 0 9 6}$ & $\mathbf{0 . 1 1 7}$ & $\mathbf{0 . 0 7 0}$ & 0.051 & - & 1.588 & 0.784 & 0.975 & 0.554 & 0.483 \\
BOA & $\mathbf{0 . 0 8 8}$ & 0.045 & 0.030 & $\mathbf{0 . 0 9 3}$ & $\mathbf{0 . 1 4 4}$ & $\mathbf{0 . 1 3 6}$ & - & 0.772 & 1.237 & 0.648 & 0.486 \\
MIL & $\mathbf{0 . 2 0 7}$ & $\mathbf{0 . 2 0 9}$ & $\mathbf{0 . 2 5 6}$ & $\mathbf{0 . 2 4 0}$ & $\mathbf{0 . 2 2 0}$ & $\mathbf{0 . 2 4 2}$ & $\mathbf{0 . 2 4 5}$ & - & 5.748 & 1.165 & 1.435 \\
DEN & $\mathbf{0 . 1 8 1}$ & $\mathbf{0 . 1 3 3}$ & $\mathbf{0 . 1 8 7}$ & $\mathbf{0 . 1 8 0}$ & $\mathbf{0 . 1 7 8}$ & $\mathbf{0 . 2 0 4}$ & $\mathbf{0 . 1 6 8}$ & 0.042 & - & 2.627 & 2.366 \\
MAC & $\mathbf{0 . 3 4 9}$ & $\mathbf{0 . 3 0 2}$ & $\mathbf{0 . 3 7 3}$ & $\mathbf{0 . 2 8 0}$ & $\mathbf{0 . 2 3 3}$ & $\mathbf{0 . 3 1 1}$ & $\mathbf{0 . 2 7 8}$ & $\mathbf{0 . 1 7 7}$ & 0.087 & - & 1.714 \\
CUR & $\mathbf{0 . 3 2 0}$ & $\mathbf{0 . 3 0 5}$ & $\mathbf{0 . 3 5 0}$ & $\mathbf{0 . 2 8 9}$ & $\mathbf{0 . 2 6 6}$ & $\mathbf{0 . 3 4 1}$ & $\mathbf{0 . 3 4 0}$ & $\mathbf{0 . 1 4 8}$ & $\mathbf{0 . 0 9 6}$ & 0.127 & - \\
\end{tabular}

Table 5. Scutellastra kermadecensis. Results of hierarchical AMOVA analysis for 2 different groupings (A and B) of northern and middle populations. See Fig. 1 for sampling site abbreviations

\begin{tabular}{|c|c|c|c|c|c|c|c|}
\hline Grouping & Source of variation & df & $\begin{array}{c}\text { Sum of } \\
\text { squares }\end{array}$ & $\begin{array}{c}\text { Estimated } \\
\text { variance }\end{array}$ & $\begin{array}{l}\text { Percentage } \\
\text { of variance }\end{array}$ & PHI-statistics & $\mathrm{p}^{\mathrm{a}}$ \\
\hline \multicolumn{8}{|c|}{ A. (DAY, WCH, NAP, NUG, MEY, EGE, BOA, MIL, DEN) vs. (MAC, CUR) } \\
\hline & Between regions & 1 & 49.188 & 0.762 & 15 & $P H I_{\mathrm{RT}}=0.152$ & $<0.001$ \\
\hline & Among populations within regions & 9 & 123.372 & 0.588 & 12 & $P H I_{\mathrm{PR}}=0.138$ & $<0.001$ \\
\hline & Within populations & 181 & 662.263 & 3.659 & 73 & $P H I_{\mathrm{PT}}=0.269$ & $<0.001$ \\
\hline \multicolumn{8}{|c|}{ B. (DAY, WCH, NAP, NUG, MEY, EGE, BOA) vs. (MAC, CUR, DEN, MIL) } \\
\hline & Between regions & 1 & 82.762 & 0.852 & 17 & $P H I_{\mathrm{RT}}=0.175$ & $<0.001$ \\
\hline & Among populations within regions & 9 & 89.798 & 0.369 & 8 & $P H I_{\mathrm{PR}}=0.092$ & $<0.001$ \\
\hline & Within populations & 181 & 662.263 & 3.659 & 75 & $P H I_{\mathrm{PT}}=0.250$ & $<0.001$ \\
\hline
\end{tabular}

MIL, DEN), ranging from 0.233 to 0.373 . These population comparisons showed low estimates of gene flow $(N \mathrm{~m})$, from 0.420 to 0.822 migrants per generation. Estimates of gene flow between MIL/DEN and some of the northern populations were also <1.0, indicating limited gene flow among these groups (Table 4). Estimates of gene flow between northern group population pairs (excluding MIL, DEN) were all >1.0.

In the assignment tests, the percentage of Siphonaria raoulensis individuals assigned to the population of collection varied from 35 to $64 \%$ (Table 6). For Scutellastra kermadecensis, CUR had the highest correct assignment rate $(95 \%)$, with the other populations ranging from 26 to $58 \%$ (Table 7 ). The assignment test results provided further evidence for the pattern of among-population gene flow indicated by $\mathrm{Nm}$ estimates. A high proportion of the 'misassigned' individuals occurred among populations within groups, whereas few individuals collected from the northern group were assigned to the middle group and vice versa (Table 7 ). When the $S$. kermadecensis assignment tests were repeated for the northern and middle groups, as revealed by the UPGMA analysis (middle group = MAC, CUR, DEN, MIL; northern group = all remaining populations), the assignment success rate was $96 \%$ for the northern group and $94 \%$ for the middle group, which was much higher than most of the success rates obtained when the 11 populations were considered separately.

Table 6. Siphonaria raoulensis. Assignment test results for individuals from each population. Values are the percentage of individuals from each collection site (rows) assigned to each population (columns). Bold indicates correct assignment. See Fig. 1 for sampling site abbreviations

\begin{tabular}{|lcccccc|}
\hline & DAY & WCH & NAP & MEY & EGE & MIL \\
\hline DAY & $\mathbf{4 1}$ & 5 & 5 & 32 & 5 & 14 \\
WCH & 5 & $\mathbf{6 4}$ & 18 & - & 5 & 9 \\
NAP & 15 & 20 & $\mathbf{4 0}$ & 15 & 5 & 5 \\
MEY & 20 & - & 15 & $\mathbf{3 5}$ & - & 30 \\
EGE & 4 & 13 & 8 & - & $\mathbf{5 8}$ & 17 \\
MIL & 12 & - & 16 & 12 & 12 & $\mathbf{4 8}$ \\
\hline
\end{tabular}


Table 7. Scutellastra kermadecensis. Assignment test results for individuals from each population. Values are the percentage of individuals from each collection site (rows) assigned to each population (columns). Bold indicates correct assignment. See Fig. 1 for sampling site abbreviations

\begin{tabular}{|lccccccccccc|}
\hline & DAY & WCH & NAP & NUG & MEY & EGE & BOA & MIL & DEN & MAC & CUR \\
\hline DAY & $\mathbf{5 7}$ & 14 & 5 & 14 & 5 & - & - & 5 & - & - & - \\
WCH & 16 & $\mathbf{2 6}$ & 21 & 10 & - & - & 21 & 5 & - & - & - \\
NAP & - & 25 & $\mathbf{3 5}$ & 20 & - & 5 & 15 & - & - & - & - \\
NUG & 10 & - & 10 & $\mathbf{4 5}$ & 10 & 5 & 10 & - & 5 & - & 5 \\
MEY & 18 & - & - & 45 & $\mathbf{2 7}$ & 9 & - & - & - & - & - \\
EGE & 10 & 5 & 10 & - & 10 & $\mathbf{5 5}$ & 5 & 5 & - & - & - \\
BOA & 11 & 11 & 28 & 11 & 11 & - & $\mathbf{2 8}$ & - & - & - & - \\
MIL & 5 & 5 & - & 5 & - & - & - & $\mathbf{5 8}$ & 21 & - & 5 \\
DEN & 6 & - & - & - & - & - & - & 22 & $\mathbf{5 0}$ & 6 & 17 \\
MAC & - & - & - & - & - & - & - & - & - & $\mathbf{5 0}$ & 50 \\
CUR & - & - & - & - & - & - & - & - & 5 & - & $\mathbf{9 5}$ \\
\hline
\end{tabular}

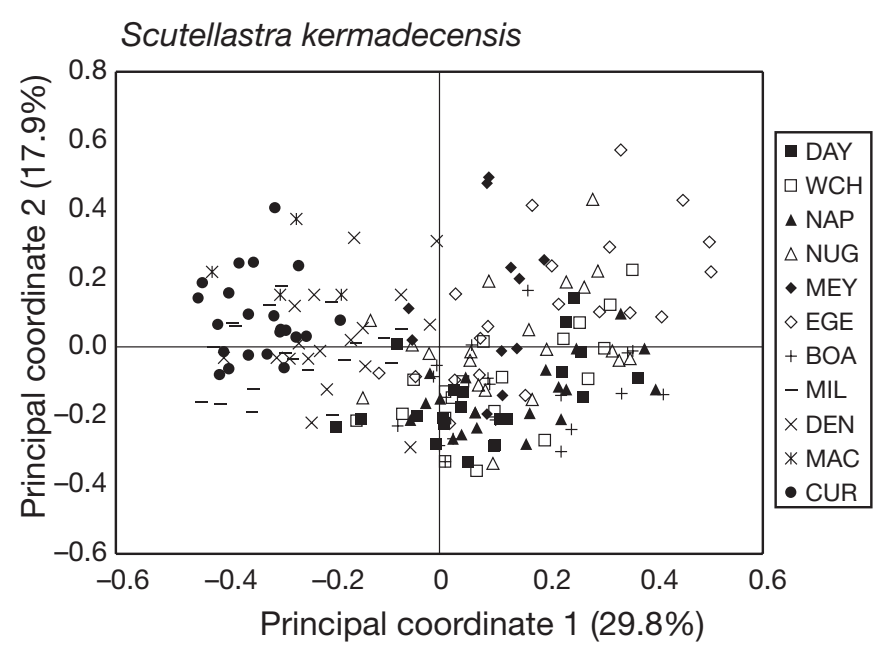

Siphonaria raoulensis

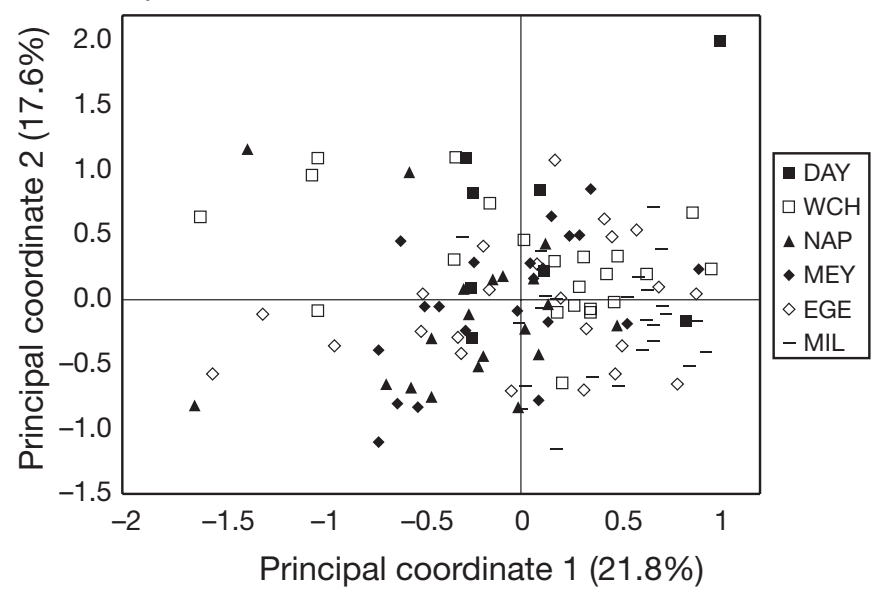

Fig. 3. Scutellastra kermadecensis and Siphonaria raoulensis. Principal coordinates analysis based on a squared Euclidean distance matrix between individuals. Percentages in parentheses indicate the proportion of the total variation explained by each principal coordinate. See Fig. 1 for sampling site abbreviations
The first 2 coordinates of the PCoA of multilocus RAPD variation explained $48 \%$ for Scutellastra kermadecensis and $39 \%$ for Siphonaria raoulensis of the variation in the respective data sets. For $S$. kermadecensis, PC1 separated the populations into 2 groups that reflect geographical location, with the split lying between a middle group (MAC, CUR, MIL and DEN) represented by negative PC1 values, and the remaining populations to the northeast of Raoul Island (Fig. 3). For $S$, raoulensis, most individuals were clustered together with only a few outliers apparent (Fig. 3). There was some separation of populations but no other grouping was evident. We found no genetic evidence for the existence of more than 1 Siphonaria species at the northern Kermadec Islands, in agreement with the morphological study by Brook (1998a).

The Mantel test revealed significant correlation of genetic distance with geographical distance between populations for Scutellastra kermadecensis for both the complete dataset $\left(\mathrm{R}_{\mathrm{xy}}=0.180, \mathrm{p}<0.001\right)$ and the 6 -population subset $\left(\mathrm{R}_{\mathrm{xy}}=0.309, \mathrm{p}<0.001\right)$. Siphonaria raoulensis showed no significant correlation between genetic distance and geographical distance $\left(\mathrm{R}_{\mathrm{xy}}=\right.$ $-0.007, \mathrm{p}=0.432$ ).

Fig. 4 shows correlograms from the spatial genetic autocorrelation analysis for 2 different distance class sizes for Scutellastra kermadecensis. In the correlogram with smaller distance classes (minimum 500 pairwise comparisons per class; Fig. 4A), the correlation between genetic and geographic distance was positive and significant from 0.5 to $4 \mathrm{~km}(0.142 \geq \mathrm{r} \geq$ 0.021, p < 0.001). At larger distances, several points showed significantly positive autocorrelation, but the general trend was toward more negative $r$ values with increasing geographic distance, a pattern that is indicative of a long-distance cline or isolation by distance (Diniz-Filho \& Telles 2002). This pattern was 


\section{Scutellastra kermadecensis}
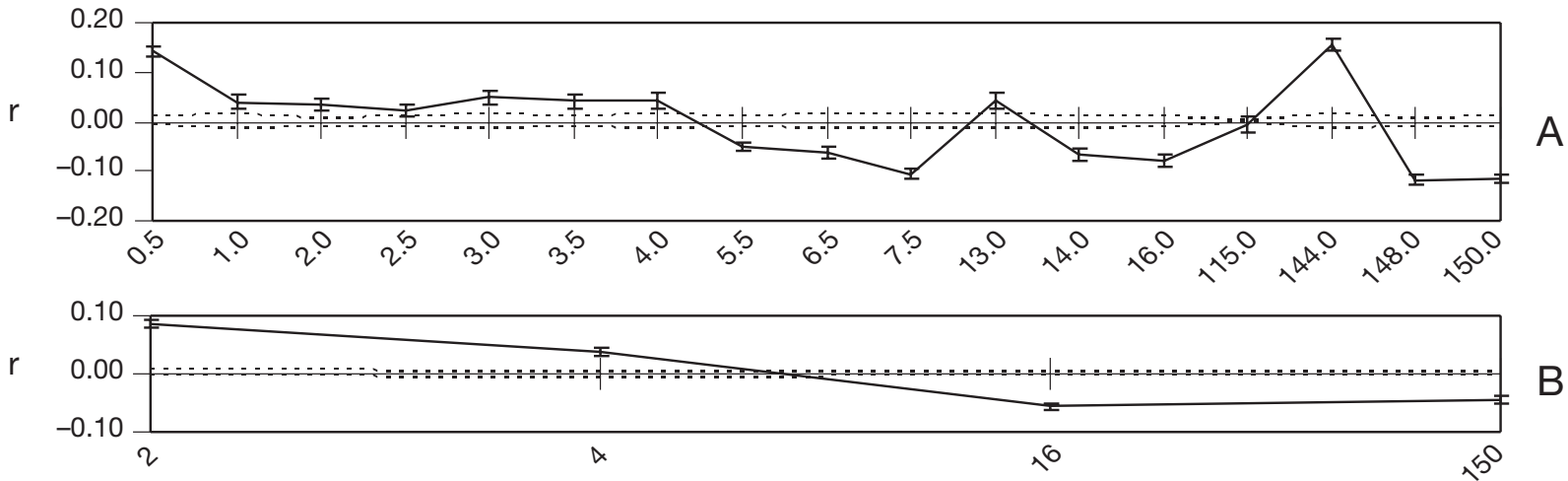

\section{Siphonaria raoulensis}

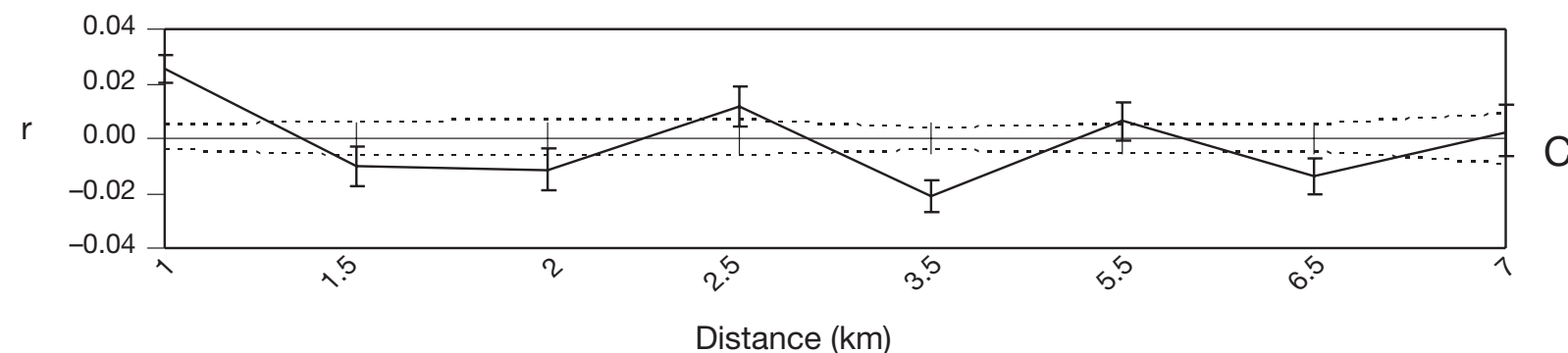

Fig. 4. Scutellastra kermadecensis (A, B) and Siphonaria raoulensis (C). Correlograms plotting spatial autocorrelation values (r) as a function of distance (solid line). Error bars indicate the $95 \%$ confidence interval about $\mathrm{r}$ from 1000 bootstrap replicates. Dotted lines mark the $95 \%$ confidence interval about the null hypothesis of no spatial structure, estimated from 9999 permutations

clearer when distance class sizes were increased (Fig. 4B). Given that clinal patterns reflecting spatially varying selection are expected to be different for different loci, the observed multi-locus correlogram pattern seems unlikely to be due to selection. Gene flow is expected to have a consistent effect across the entire genome, and isolation by distance was already inferred for $S$. kermadecensis by a Mantel test (above). Closer examination of the sites contributing to each distance class in Fig. 4A revealed that the significantly positive points ( 0.5 to 4,13 and $144 \mathrm{~km}$ ) almost always involved comparisons between sites within either the northern or middle group (as defined by UPGMA and PCoA analyses). Comparisons between sites from different groups (i.e. northern vs. middle; 5.5 to $7.5,14$ to 16,148 to $150 \mathrm{~km}$ ) showed significantly negative autocorrelation, suggesting that factors other than isolation by distance have contributed to the genetic variation between northern and middle sites. The correlogram for Siphonaria raoulensis showed a small, but significant, $\mathrm{r}$ value in the shortest distance class $(0$ to $1 \mathrm{~km}, \mathrm{r}=0.025, \mathrm{p}<$ 0.001 ), and fluctuation of $r$ values around 0 at longer distances (Fig. 4C), a pattern indicative of patch structure (Smouse \& Peakall 1999, Diniz-Filho \& Telles 2002).
The spatial autocorrelation analyses performed for Scutellastra kermadecensis with increasing distance class sizes (Fig. 5) revealed that $r$ values for the shortest distance class remained significantly positive from 0.5 to $149 \mathrm{~km}(0.142 \geq \mathrm{r} \geq 0.006, \mathrm{p}<0.001)$. This indicates that positive spatial genetic structure extends throughout the range of this species. For Siphonaria raoulensis, distance class sizes of 1 to $3 \mathrm{~km}$ showed significant positive $r$ values $(0.025 \geq \mathrm{r} \geq 0.004, \mathrm{p}<0.001)$. At distance class sizes of $3.5 \mathrm{~km}$ and greater, $\mathrm{r}$ was not significantly different from 0 ; therefore, our data indicate that positive spatial genetic structure in Siphonaria raoulensis extends for at least $3 \mathrm{~km}$.

\section{DISCUSSION}

Our analysis of genetic variation using RAPD markers revealed significant small-scale population genetic subdivision in 2 limpet species endemic to the Kermadec Islands, New Zealand. There was evidence of moderate genetic subdivision and restricted gene flow between northern and middle groups for Scutellastra kermadecensis from the hierarchical AMOVA, PCoA and UPGMA analyses. For comparison, the amongregion variation estimated by AMOVA for $S$. kerma- 


\section{Scutellastra kermadecensis}

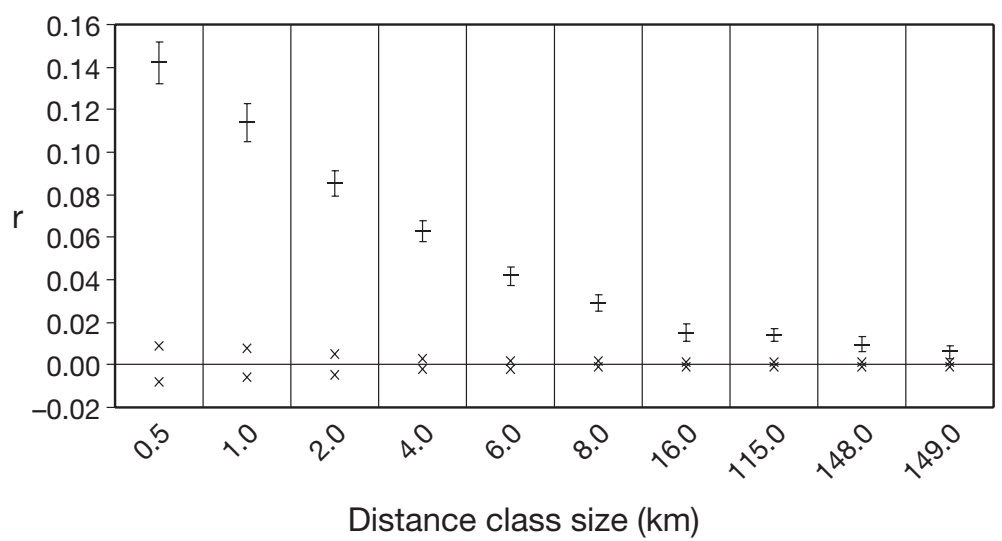

Siphonaria raoulensis

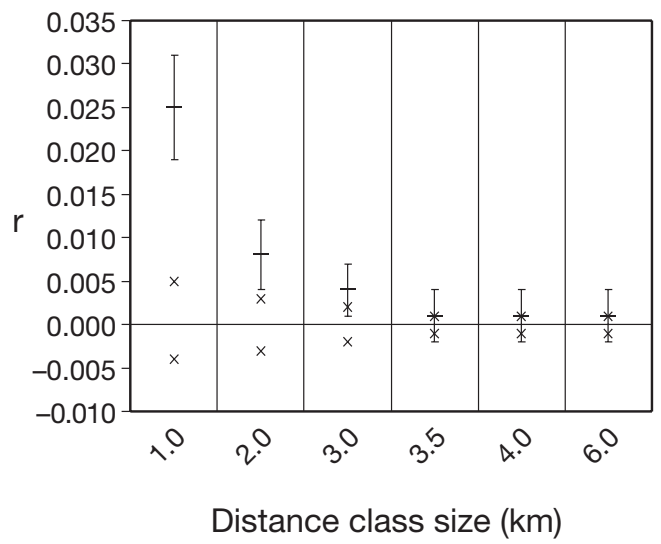

Fig. 5. Scutellastra kermadecensis and Siphonaria raoulensis. Spatial autocorrelation values (r) for increasing distance class sizes (solid line), with $95 \%$ confidence error bars as determined by 1000 bootstrap replicates. Crosses mark the $95 \%$ confidence interval about the null hypothesis of no spatial structure, as determined by 9999 permutations

decensis $\left(P H I_{\mathrm{RT}}=0.175\right)$ was less than that observed in the endangered giant Mediterranean limpet Patella ferruginea between 2 Sardinian marine protected areas $110 \mathrm{~km}$ apart $\left(P H I_{\mathrm{RT}}=0.452\right.$, estimated from inter-simple sequence repeat [ISSR] markers; Casu et al. 2006), but greater than that among North and South Island (New Zealand) populations of the greenshell mussel Perna canaliculus $(\theta=0.092$, from RAPDs; Star et al. 2003). Although the genetic subdivision among northern and middle populations of S. kermadecensis can at least partly be attributed to the effect of isolation by distance, we note that the populations on the southern side of Raoul Island (MIL and DEN) were consistently grouped with the Macauley and Curtis Island populations (middle group) rather than with geographically closer populations on the northeast side of Raoul Island. This suggests that a barrier to north-south gene flow occurs on the eastern side of Raoul Island, in the vicinity of Wilson Point (see Fig. 1), perhaps as a result of local current patterns. If this is the case, we would expect to find similar population genetic structuring in other species with similar reproductive strategies. For Siphonaria raoulensis, the Milne Islets population was the most southerly population studied and showed only slight genetic differentiation from the other northern populations. Data from additional sites will be necessary to determine whether this barrier also affects $S$. raoulensis. Surface current patterns in the Kermadec Islands are poorly known, but the main water flow is thought to be from the west and southwest (Brook 1998a and references therein), which may result in infrequent dispersal events from Curtis and/or Macauley Islands to the southern side of Raoul Island. Estimates of gene flow (from Nm and assign- ment tests) between the middle and northern groups are highest between MAC/CUR and DEN/MIL populations and low between MAC/CUR and the other northern populations, consistent with infrequent dispersal events from CUR/MAC to DEN/MIL and very restricted dispersal beyond this to the populations north of Wilson Point. Assignment tests showed that all MAC and $95 \%$ of CUR individuals were assigned to either MAC or CUR; however, the remaining $5 \%$ of CUR individuals were assigned to the Denham Bay population, suggesting that limited southward dispersal may also occur.

Among the populations to the northeast of Raoul Island (small scale: 0.4 to $7.1 \mathrm{~km}$ between populations), estimates of population genetic structuring for both species were low but significant, indicating that gene flow is moderately restricted among these sites. The conclusion that a low to moderate degree of selfrecruitment occurs within these northern populations was further supported by the assignment tests, where 26 to $64 \%$ of individuals were assigned to their population of collection. Genetic differentiation between populations to the south and north of Raoul was high relative to differentiation within these regions, e.g. $P H I_{\mathrm{PT}}$ values for pairwise comparisons between Denham Bay and the northeast Raoul populations (geographic distance $=12$ to $15 \mathrm{~km}$ ) were 3 to 5 times higher than for the comparison between the Milne Islets and Denham Bay populations separated by a similar distance. Within the middle group of islands, moderately high estimates of population genetic structuring between the Macauley and Curtis populations and the very high assignment success (95\%) observed for Curtis Island individuals suggest that a high proportion of recruitment to these populations is local. 
The Mantel test and spatial autocorrelation analyses showed a clear pattern of isolation by distance in Scutellastra kermadecensis, with positive spatial genetic structure extending throughout the geographic range sampled. The declining relatedness between individuals with increasing geographic distance provides further evidence that gene flow is restricted within the $150 \mathrm{~km}$ range studied for $S$. kermadecensis. In Siphonaria raoulensis, positive spatial genetic structure was weaker than that observed in $S$. kermadecensis and extended for only $3 \mathrm{~km}$, beyond which our analyses suggest the random effects of genetic drift, rather than gene flow, were the primary determinants of genetic composition. The spatial autocorrelation analysis indicated a pattern of microspatial genetic structure for $S$. raoulensis. Examination of pairwise population $P H I_{\mathrm{PT}}$ values for $S$. raoulensis revealed that 7 of 15 comparisons were higher than the overall $P H I_{\mathrm{PT}}$ value. This pattern of local heterogeneity and low genetic subdivision over wider areas has been observed in another Siphonaria sp., for which evidence has been provided that the local genetic patchiness is ephemeral as a result of spatially patchy recruitment and temporal variation in the genetic composition of recruits (Johnson \& Black 1984). If local genetic patchiness is stable over time and/or across age groups, this could be explained by predominantly local recruitment with low-level dispersal over greater distances, as has been suggested for Roe's abalone (Hancock 2000). Combinations of either local recruitment and homogenising selection, or wider-scale dispersal and local post-settlement selection, could also produce a patchy genetic structure. Further data would be necessary to determine the stability and causes of the pattern of genetic structure in $S$. raoulensis.

Where gene flow is restricted, population fragmentation can lead to inbreeding and loss of genetic diversity within fragments, with negative consequences for long-term persistence and evolutionary potential (Frankham et al. 2002). For Scutellastra kermadecensis populations, genetic diversity estimates were generally lower than those observed in related species, e.g. Patella ferruginea: $0.17<H<0.23$, using ISSR markers (Casu et al. 2006); and P. aspera and P. ulyssiponensis: mean $H=0.206$, using allozyme markers (Weber \& Hawkins 2005). Genetic diversity for Siphonaria raoulensis was higher than that for S. kermadecensis, but toward the lower end of the range of genetic diversity estimates from a RAPD marker study of 12 other Siphonaria species (0.17 to 0.46 ; Chambers et al. 1998). The evidence for restricted gene flow among northern and middle $S$. kermadecensis populations suggests that the Curtis and Macauley Island populations, which are small and geographically isolated from the other populations, and appear to rely mainly on self- recruitment, could be at particular risk of inbreeding and loss of genetic variability. The Curtis Island population showed low genetic diversity and percentage of polymorphic loci relative to the other populations and, in addition, had 2 private bands. This is consistent with a long-term predominance of self-recruitment and associated loss of genetic diversity. For the Macauley Island population, genetic diversity estimates and percentage of polymorphic loci were above average, but these estimates may not be reliable because of the small sample size for this population ( $\mathrm{n}=4$ individuals).

Recent evidence from direct studies of larval dispersal (e.g. Swearer et al. 1999) and oceanographic models (e.g. Cowen et al. 2006) suggests that the majority of larvae may settle close to where they were produced. Previous genetic evidence for local retention of larvae with high dispersal potential has been found mainly at moderate spatial scales of $10 \mathrm{~s}$ to $100 \mathrm{~s}$ of $\mathrm{km}$ (e.g. Taylor \& Hellberg 2003), although a recent allozyme study of an intertidal snail in the Houtman Abrolhos Islands (Western Australia) found low population connectivity on the scale of a few $\mathrm{km}$ (Johnson \& Black 2006). The present study provides evidence of self-recruitment at small spatial scales in Kermadec Island populations of a broadcast spawning species with a planktonic larval stage (Scutellastra kermadecensis) and a second species with unknown reproductive strategy (Siphonaria raoulensis). Populations of these limpets separated by as little as $0.4 \mathrm{~km}$ showed statistically significant genetic differentiation, and estimates of gene flow indicated limited population connectivity both within and among island groups, suggesting that a large proportion of successfully recruiting larvae are retained very close to their population of origin. Patterns of connectivity among populations were related to the extent of geographic separation in $S$. kermadecensis throughout the $150 \mathrm{~km}$ range studied, whereas $S$. raoulensis showed positive spatial genetic structure for only $3 \mathrm{~km}$, highlighting differences in population connectivity between these species. There was strong evidence for other, perhaps more significant, barriers to gene flow, probably resulting from localised current regimes around the Kermadec Islands. A high capacity for local selfrecruitment may be advantageous for maintenance of populations in isolated habitats such as the Kermadec Islands. However, populations (or species) reliant on self-recruitment are especially vulnerable to local extinctions resulting from of natural or human-mediated events. As noted by Johnson \& Black (2006), most evidence to date for self-recruitment in marine species comes from island populations, and further studies are required to determine whether similar patterns occur in other situations. 
Acknowledgements. We are grateful to J. Allen, M. Curwen, J. Long, K. Steger, R. Williamson and the crews of the 'Braveheart' (July 2002) and 'Southern Salvor' (November 2004) for assistance with sample collection, and to R. Procter for help with some of the DNA extractions. Samples were collected under authority of New Zealand Department of Conservation permit numbers AKDCO-33766 (July 2002) and AKDCO52675 (November 2004) issued to J.P.A.G. This research was supported by a post-doctoral fellowship to A.R.W, that funding having been awarded to J.P.A.G by the Victoria University of Wellington (NZ) University Research Fund, for whose ongoing support of our work into Polynesian marine biogeography and population genetics we are most grateful. We thank 2 anonymous reviewers for helpful comments and suggestions that improved this paper.

\section{LITERATURE CITED}

Berry O, Tocher MD, Sarre SD (2004) Can assignment tests measure dispersal? Mol Ecol 13:551-561

Brook FJ (1998a) The coastal molluscan fauna of the northern Kermadec Islands, Southwest Pacific Ocean. J R Soc N Z 28: 185-233

Brook FJ (1998b) Stratigraphy and paleontology of Pleistocene submarine volcanic-sedimentary sequences at the northern Kermadec Islands. J R Soc N Z 28:235-257

Casu M, Casu D, Lai T, Cossu P, Curini-Galletti M (2006) Intersimple sequence repeat markers reveal strong genetic differentiation among populations of the endangered mollusc Patella ferruginea (Gastropoda: Patellidae) from two Sardinian marine protected areas. Mar Biol 149:1163-1174

Chambers RJ, McQuaid CD, Kirby R (1998) The use of randomly amplified polymorphic DNA to analyze the genetic diversity, the systematic relationships and the evolution of intertidal limpets, Siphonaria spp. (Pulmonata: Gastropoda), with different reproductive modes. J Exp Mar Biol Ecol 227:49-66

Cole RG, Creese RG, Grace RV, Irving P, Jackson BR (1992) Abundance patterns of subtidal benthic invertebrates and fishes at the Kermadec Islands. Mar Ecol Prog Ser 82: 207-218

Cowen RK, Paris CB, Srinivasan A (2006) Scaling of connectivity in marine populations. Science 311:522-527

Creese RG, Schiel DR, Kingsford MJ (1990) Sex change in a giant endemic limpet, Patella kermadecensis, from the Kermadec Islands. Mar Biol 104:419-426

Diniz-Filho JAF, Telles MPC (2002) Spatial autocorrelation analysis and the identification of operational units for conservation in continuous populations. Conserv Biol 16: 924-935

Dodd JM (1957) Artificial fertilisation, larval development and metamorphosis in Patella vulgata L. and Patella coerulea L. Pubbl Stn Zool Napoli 29:172-186

Fleming CA (1973) Kermadec Island giant limpet occurring fossil in New Zealand, and relict distributions in the tropics. N Z J Mar Freshw R 7:159-164

Frankham R, Ballou JD, Briscoe DA (2002) Introduction to conservation genetics. Cambridge University Press, Cambridge

Hancock B (2000) Genetic subdivision of Roe's abalone, Haliotis roei Grey (Mollusca: Gastropoda), in south-western Australia. Mar Freshw Res 51:679-687

Hodgson AN (1999) The biology of Siphonariid limpets (Gastropoda: Pulmonata). Oceanogr Mar Biol Annu Rev 37: 245-314

Isabel N, Beaulieu J, Theriault P, Bousquet J (1999) Direct evi- dence for biased gene diversity estimates derived from dominant random amplified polymorphic DNA (RAPD) fingerprints. Mol Ecol 8:477-483

Johnson MS, Black R (1984) Pattern beneath the chaos: the effect of recruitment on genetic patchiness in an intertidal limpet. Evolution 38:1371-1383

Johnson MS, Black R (2006) Islands increase genetic subdivision and disrupt patterns of connectivity of intertidal snails in a complex archipelago. Evolution 60:2498-2506

Krauss SL (2000) Accurate gene diversity estimates from amplified fragment length polymorphism (AFLP) markers. Mol Ecol 9:1241-1245

Lessios HA, Kessing BD, Robertson DR (1998) Massive gene flow across the world's most potent marine biogeographic barrier. Proc R Soc Lond B 265:583-588

Lindberg DR (1988) The Patellogastropoda. Malacol Rev S4:35-63

Lloyd EF, Nathan S (1981) Geology and tephrochronology of Raoul Island, Kermadec Group, New Zealand. N Z Geol Surv Bull 95:1-105

Neigel JE (2002) Is $F_{\mathrm{ST}}$ obsolete? Conserv Genet 3:167-173

Oliver W (1915) The Mollusca of the Kermadec Islands. Trans Proc N Z Inst 47:509-568

Paetkau D, Calvert W, Stirling I, Strobeck C (1995) Microsatellite analysis of population structure in Canadian polar bears. Mol Ecol 4:347-354

Peakall R, Smouse PE (2006) GenAlEx 6: genetic analysis in Excel. Population genetic software for teaching and research. Mol Ecol Notes 6:288-295

Peakall R, Ruibal M, Lindenmayer DB (2003) Spatial autocorrelation analysis offers new insights into gene flow in the Australian bush rat, Rattus fuscipes. Evolution 57:1182-1195

Rice WR (1989) Analyzing tables of statistical tests. Evolution 43:223-225

Scheltema RS (1986) On dispersal and planktonic larvae of benthic invertebrates: an eclectic overview and summary of problems. Bull Mar Sci 39:290-322

Smouse PE, Peakall R (1999) Spatial autocorrelation analysis of individual multiallele and multilocus genetic structure. Heredity 82:561-573

Star B, Apte S, Gardner JPA (2003) Genetic structuring among populations of the greenshell mussel Perna canaliculus revealed by analysis of randomly amplified polymorphic DNA. Mar Ecol Prog Ser 249:171-182

Swearer SE, Caselle JE, Lea DW, Warner RR (1999) Larval retention and recruitment in an island population of a coral reef fish. Nature 402:799-802

Swofford DL (2002) PAUP*: phylogenetic analysis using parsimony $\left({ }^{*}\right.$ and other methods). Sinauer, Sunderland, MA

Taylor MS, Hellberg ME (2003) Genetic evidence for local retention of pelagic larvae in a Caribbean reef fish. Science 299:107-109

Vekemans X (2002) AFLP-SURV version 1.0. Distributed by the author. Laboratoire de Génétique et Ecologie Végétale, Université Libre de Bruxelles

Weber LI, Hawkins SJ (2005) Patella aspera and P. ulyssiponensis: genetic evidence of speciation in the North-east Atlantic. Mar Biol 147:153-162

Welsh J, McClelland M (1990) Fingerprinting genomes using PCR with arbitrary primers. Nucleic Acids Res 18: $7213-7218$

Whitlock MC, McCauley DE (1999) Indirect measures of gene flow and migration: $F_{\mathrm{ST}} \neq 1 /(4 N m+1)$. Heredity 82 : $117-125$

Zhivotovsky LA (1999) Estimating population structure in diploids with multilocus dominant DNA markers. Mol Ecol 8:907-913 